\title{
GLOSS TO THE RESOLUTION OF THE SUPREME COURT OF 26 FEBRUARY 2021, III CZP 24/20 [ON THE INTERPRETATION OF THE WILL] ${ }^{1}$
}

\author{
Pawet Zdanikowski*
}

\begin{abstract}
The resolution with gloss concerns the rules for interpreting a will. The Supreme Court stated in it that an interpretation of a will should be performed taking into account all circumstances, including those external to the will and using all means of evidence. The Supreme Court decided that it is the court adjudicating in the case for inheritance acquisition, assessing the evidence gathered in a specific case, that should assess whether it is actually possible to establish the will of the testator. The author of the gloss accepts the thesis of the resolution, but argues with the position of the Supreme Court contained in its justification that only the rules for evidence assessment constitute an instrument allowing one to establish the testator's will. In the opinion of the author of the gloss the functional interpretation of Art. 948 of the Polish Civil Code (k.c.) indicates limits to the interpretation of the will. After all this is a process that renders it possible to determine the testator's will in a manner that does not raise any doubts. Therefore, if the interpretation of the will of such fails to secure such a degree of certainty, even despite a positive assessment of the evidence gathered in the case, the court should state that the inheritance has been acquired under the Act.
\end{abstract}

Keywords: freedom of testation, interpretation of a will, external circumstances in interpreting a will

* Dr. Paweł Zdanikowski, Assistant Professor, Faculty of Law, Canon Law and Administration, The John Paul II Catholic University of Lublin; correspondence address: Al. Racławickie 14, 20-950 Lublin, Poland; e-mail: pawel.zdanikowski@kul.pl; https:// orcid.org/0000-0002-2383-5401.

Biuletyn Sądu Najwyższego 2021, nr 2. 


\section{The thesis of the resolution that is subject to the gloss reads:}

"A will should be interpreted taking into account the circumstances of its making, which can be established with the use of any means of evidence."

The resolution is worth attention for at least two reasons. Firstly, it was set against the background of an interesting state of affairs that is rarely occurring in practice, and perhaps even unique. Secondly, it concerns issues that cause very serious judicial difficulties to courts hearing cases for confirmation of inheritance acquisition. Although the resolution formally concerns the interpretation of the will using non-testamentary sources of information about the will of the testator, its practical significance rests in the attempt by the Supreme Court to define the limit of interpretation of the will, which - of course - proves to pose a very difficult task.

The resolution was adopted against the background of the following facts. The testator left a handwritten will with the following content: "After settling any obligations, my property should be divided equally among my friends (men in my photo) (...).” The testator signed the will, indicating the place and date. However, no photo was attached to the will, but, in the personal belongings of the testator in his locker at work, a color A4 format copy of a collage of 9 photos of 11 men and photos of photographs of other friends were found.

The court hearing the case for inheritance acquisition at first instance found the will valid, but ineffective. The district court stated that if the heir was not explicitly named, the will must contain indications allowing the testator's intention to be stated in a manner that does not raise reasonable doubts. The determination of the heir may be the result of an interpretation aimed at the fullest possible implementation of the testator's will (Art. $948 \$ 1$ of the Civil Code) and take into account all circumstances that assist this process, including external ones (e.g. the testator's declaration related to the content of the will, but not included in it), however, these rules may only serve to remove ambiguities contained in the testator's last will, and they cannot supplement or modify the content of the will. Therefore, they do not allow for the determination of the person appointed testates based on the phrase: "my friends - men from the photo" in a situation where the photo was not attached to the will and the testator had many photos of friends. The court of first instance 
also found that in the evidence collected there was no confirmation that the collage submitted to the file was a photograph referred to by the testator. It considered the fact that his photocopy was known to some participants in the proceedings insufficient, particularly since not all participants saw the connection between the collage and the will, and there was a difference between the concepts of "photo" and "photo collage". It assessed the applicant's testimony, which referred to the collage, as unreliable, as it did with the statements of other participants inspired by its position. Consequently, the district court stated that establishing the heirs by way of interpretation would, in this particular case, constitute an inadmissible supplementation to the content of the will.

When examining the applicant's appeal, the regional court raised two fundamental doubts. First, whether, in the case of a holographic will, the meaning of an unclear testamentary disposition determining the heir can be determined on the basis of the testimony of witnesses or persons having interest in inheriting. Secondly, whether the determination of the grounds for determining the heir is effective in a will only if it makes it possible to establish the will of the heir beyond any doubt.

The Supreme Court, distancing itself a bit from the facts of the case, replied on a higher level of generality than that most likely expected by the questioning court and, answering both questions, stated that "the will should be interpreted taking into account the circumstances of its preparation, which can be established with the use of any evidence".

In its arguments, the Supreme Court started from the premises, already well-established both in the jurisprudence and in the literature, that the heir does not have to be named in a will, and it is sufficient to indicate him or her in any way that renders their identification possible. If such a definition of the heir is not precise enough, it is necessary to try to determine its meaning by referring to additional guidelines, including those that are external to the content of the will. In the opinion of the Supreme Court, when interpreting such a will, in addition to its text and linguistic rules of meaning, one should take into account the circumstances of its making, i.e. those that occurred before the declaration of will and accompanying its submission. These circumstances can be verified by any evidence, including evidence from the testimony of witnesses or from the questioning of the parties (such evidence is not directed against 
the basis of the document, but is used to establish, by way of interpretation, unclear declarations of will contained in the document). There are also no formal limitations of evidence resulting from the provisions which stipulate that certain categories of persons may not be witnesses when making a will, e.g. because the will provides for some benefit for them (cf. Art. 957 of the Civil Code). On the other hand, circumstances that are relevant in the light of these provisions may be relevant when assessing the credibility and probative value of the evidence (cf. Art. $233 \$ 1$ of the Polish Code of Civil Procedure). The option of applying all means of evidence in such a situation (including evidence from the testimonies of witnesses and from the questioning of the parties) is also recognized in the jurisprudence in de lege lata. If, after resorting to non-substantive interpretative guidelines and the use of additional evidence (including testimonial evidence), the meaning of a testamentary provision specifying persons appointed to testate can be clarified, we cannot question its effectiveness. Also with the assumption - albeit questioned by some experts - that Art. $948 \$ 2$ of the Civil Code does not allow supplementing the content of a will, for example by applying the so-called supplementary interpretation. For it is something else (interpretation) to determine the person appointed as an heir in a situation in which the testator undoubtedly had a specific person in mind, and the doubt concerns only identification of such person, and another (supplement) to define the heir when the testator did not make a specific decision in this respect, confining only to general guidelines that may apply to an unspecified circle of people. Although the Supreme Court admitted that in borderline cases this distinction may raise some doubts, however, they do not apply to the circumstances of the present case, because the indication as heirs of "friends (men in my photo)" allows it to be considered, especially taking into account Art. $948 \$ 2$ of the Civil Code, stating that the deceased made and expressed a decision as to the circle of heirs (he meant specific men, from a specific photo), but he did so imprecisely, because he did not directly indicate which photo was meant. Nevertheless, this lack of precision does not in itself rule out the effectiveness of the disposition, as it remains possible to specify it on the basis of additional circumstances, also when the deceased had many photos. Then, further external circumstances may be important, such as the intensity of personal ties with in- 
dividuals or any statements made during the testator's lifetime regarding the appointment of heirs. Ultimately, whether it is actually possible to determine the testator's will is determined by the evidence collected in a specific case and its assessment by the court, therefore this issue cannot be resolved in an abstract manner. Nevertheless, the Supreme Court emphasized that in such cases, Art. $948 \$ 2$ of the Civil Code speaks in favour of not only assuming that the testator, who was vaguely expressing his will, had a circle of specific heirs in mind, but also that when specifying these persons, the decisive importance should be attributed not as much to the absolute certainty of the result as to its rationality, because this criterion is referred to by the legislator in the said provision.

The thesis formulated by the Supreme Court raises no doubt and should be fully shared. It should be remembered, however, that it was formulated at a fairly high level of generality, and therefore it is not controversial in itself. Moreover, it strengthens the previous jurisprudence in this respect. However, a closer analysis of the legal questions, especially the second one and the justification of the resolution, is somewhat polemical. Regardless of the accuracy of the resolution itself, one can doubt whether the Supreme Court did not allow the limits of the interpretation of the will to be exceeded in justifying its position.

The provision defining the rules for interpreting a will is Art. 948 of the Civil Code. It requires that the will should be interpreted in such a manner as to ensure the fullest possible implementation of the testator's will $(\$ 1)$, and if the will can have various interpretations, it should be interpreted in such a way that the testator's orders should be kept in force and given reasonable content $(\$ 2)$.

Article 948 of the Civil Code does not regulate the admissibility of taking into account circumstances that are external in relation to the content of the interpreted will. Despite this, both the jurisprudence and the literature rightly assume that - as a rule - taking into account such circumstances in 
the interpretation is permissible ${ }^{2}$, and sometimes it is even stated (rightly) that it is necessary ${ }^{3}$. The jurisprudence and literature to date, however, feature examples of such circumstances (mainly for the purposes of determining the animus testandi), such as the level of intelligence and education of the testator, knowledge (ignorance) of the rules for making and executing wills, psychophysical condition of the author of the disposition at the time of testing (e.g. agonal state resulting from the stage of the disease, waiting for a complicated surgical procedure, and even the testator's subjective feeling of coming death), the testator's relationship with the family and people outside the family, the content of previously made wills ${ }^{4}$, all oral and written statements of the testator (e.g. draft of the will, letters, notes, explanations provided to the witnesses of the will, both before, during and after the testation), personal characteristics, features of the environment in which the testator lived, local customs, including language customs in the testator's environment ${ }^{5}$, the relationship between the testator and others subjects, not only heirs (including personal relationships, sympathies, but also hatred of certain people), views and broadly understood lifestyle of the testator, as well as his or her manner of expression (e.g. calling of a person unrelated to the testator "brother") ${ }^{6}$. The conviction that

2 Cf. Decisions of the Supreme Court of 28 October 1997, I CKN 276/97, OSNC 1998, No. 4, item 63; 13 February 2001, II CKN 378/00; 13 June 2001, II CKN 543/00, OSNC 2002, No. 1, item 14; 6 May 2005, II CK 676/04; 14 July 2005, III CK 694/04; 6 October 2016, IV CSK 825/15; Judgment of the Supreme Court of 5 September 2008, I CSK 51/08. In the literature, see Jan Gwiazdomorski, Prawo spadkowe w zarysie (Warszawa: Państwowe Wydawnictwo Naukowe, 1985), 116; Konrad Osajda, in Kodeks cywilny. Komentarz. Tom III. Spadki (art. 922-1088), ed. Konrad Osajda (Warszawa: C.H. Beck, 2013), 326-327; Maciej Rzewuski, "Wykładnia słusznościowa testamentu," Biatostockie Studia Prawnicze, no. 17 (2014): 231; Maciej Rzewuski, "Wykładnia testamentu a okoliczności zewnętrzne towarzyszące testowaniu," Przegląd Sądowy, no. 1 (2015): 113; Jacek Wierciński, "Uwagi o zamiarze testowania," Przegląd Sądowy, no. 7-8 (2012): 140.

3 So Rzewuski, "Wykładnia słusznościowa testamentu," 231.

4 Cf. Wierciński, "Uwagi o zamiarze testowania," 140; Rzewuski, "Wykładnia testamentu a okoliczności zewnętrzne towarzyszące testowaniu," 113.

5 Sylwester Wójcik, "Rozrządzenia testamentowe," in System Prawa Cywilnego, Tom IV, Prawo spadkowe, ed. Józef Stanisław Piątowski (Wrocław-Warszawa-Kraków-Gdańsk: Wydawnictwo Polskiej Akademii Nauk, 1986), 219.

6 Michał Niedośpiał, Testament. Zagadnienia ogólne testamentu w polskim prawie cywilnym (Kraków-Poznań: Polski Dom Wydawniczy „Ławica” 1993), 171. 
the use of extra-testament circumstances allowing for the correct reading of the testator's intentions is also confirmed by the jurisprudence allowing for proving the content of a holographic will and the circumstances of its making in correct form ${ }^{7}$, establishing the fact of making a holographic will and its content only on the basis of witnesses' testimonies ${ }^{8}$, allowing for proof of the content of a lost holographic will on the basis of a photocopy ${ }^{9}$, or allowing the determination of the content of a letter stating the content of a lost or damaged oral will, even after the deadlines specified in Art. 952 $\$ 2$ and 3 of the Civil Code ${ }^{10}$.

There are also no obstacles to clarify the identity of the heir by interpreting the will. In this respect, the testator's ability to use terms indicating the degree of kinship, or other circumstances allowing for the identification of the heir, e.g. "my eldest son" or "my only niece", etc., is unquestionable. The testator also described the heirs in the actual state of the case on the basis of which the voted resolution was adopted in a similar way. The testator described his heirs there as "friends" and, in addition, referred in this respect to a photograph which he failed to specify, in which "friends" were to appear.

The issue of a will referring to another document on the basis of which the testator's intention can be established has already been noticed in Polish literature. M. Rzewuski, referring to Swiss and German literature, which - with the proviso that it may not lead to supplementation of the content of the will - allow references to other documents in wills - postulates to introduce the institution of references in the content of the will to other documents into the Polish legal system. On the other hand he does not exclude using references to this type of documents in the current legal system. Since the legislator did not introduce an explicit prohibition in this matter to the code, then, according to lege non distinguente principle, such

7 Cf. the resolution of the Supreme Court of 29 May 1987, III CZP 25/87, OSNCP 1988, No. 9, item 117.

8 Cf. the decision of the Supreme Court of 20 July 2005, II CK 2/05.

9 Cf. the decision of the Supreme Court of 16 April 1999, II CKN 255/98, OSNC 1999, No. 11, item 194.

${ }_{10}$ Cf. the decision of the Supreme Court of 6 March 1975, III CRN 450/74, OSPiKA 1976, No. 8, item 147 and the resolution of the Supreme Court of 13 November 1992, III CZP 120/92, OSNC 1993, No. 3, item 26. 
a possibility appears to be entirely allowed ${ }^{11}$. Indeed, there are no normative obstacles to taking the circumstances contained in other documents to which the will refers, when interpreting a will. On the other hand, even intuitively it seems that there must be some limit to the permissibility of making such determinations. This is particularly so in those cases, where through the interpretation of the will, the identity of the heir should be specified. The need to draw such a border is also noticed by the previous jurisprudence of the Supreme Court, which indicates that the determination of an heir through the interpretation of a will is possible only if the will contains objective, unambiguous and proven criteria that allow to determine the will of the testator in a way that does not raise any doubts ${ }^{12}$. It should also be assumed that the Supreme Court also had (on the basis of the case for establishing the content of a lost holographic will) such a limit in mind, by stating that the testimony of witnesses testifying in such a case should be assessed with particular insight and caution, especially when there is no trace of written evidence confirming the fact making a will, which may facilitate possible manipulations and fraud ${ }^{13}$. It is also in the justification of the resolution, subject to the gloss, that such a "boundary" is set by the Supreme Court, however, it sees it in the rules of assessing the evidence collected in the case. The issue, however, is that these rules may not prove sufficient. The collected evidence may be reliable in a formal sense (e.g. documents undoubtedly originating from the testator or clear and firm testimonies of witnesses who are strangers to the participants to the proceeding), and yet they may not give us certainty in determination of the heir. For example: in a case with facts similar to that assessed by the Supreme Court, it could have happened that the interviewed witnesses testified honestly and, thanks to their testimony, the court was able to establish the identity of the persons shown in the photograph. However, this does not in any way remove the uncertainty arising from the lack of a link between the will and the "appendix" thereto. Therefore, the lack of such

11 Rzewuski, "Wykładnia testamentu a okoliczności zewnętrzne towarzyszące testowaniu," 115-119.

12 As an example, the Supreme Court in the justification of the decision of 13 June 2001, II CKN 543/00.

13 Cf. the decision of the Supreme Court of 20 July 2005, II CK 2/05. 
a link causes the degree of certainty of the interpretation result to decrease, even when we assume a positive evaluation of the evidence. Therefore, it is necessary to search for another rule that would allow for defining the limit of the interpretation of a will. For this, we need to re-examine Art. 948 of the Civil Code to consider, whether the answer to this question will not be provided by a functional interpretation of this provision.

The main purpose of Art. 948 of the Civil Code is to support the realization (implementation) of one of the basic principles of inheritance law, which is the freedom of testation. Without specific rules for interpreting a will, many testators, due to the lack of skills or the ability to precisely define the heir, or express the will to test, might not effectively appoint them. Should this provision not apply, the will should be interpreted on general principles, i.e. based on the objective interpretation of declarations of will. However, in the area of appointing an heir, the freedom of testation is not an absolute value. It must take into account a certain degree of certainty concerning the appointment of heirs. Therefore, since the implementation of the freedom of testation means excluding persons closest to the testator (most often close family members) from the inheritance, then taking into account, for example, the constitutional principle of protection of family (Art. 18 of the Polish Constitution), it must be expressed as certainly as possible. It is doubtful that the legislator accepts the risk of not quite surely appointing a testamentary heir, while at the same time providing wide possibilities in terms of the form of testation. After all, the testator has a choice of a notarial form, which almost completely excludes the risk of imprecise identification of the heir, so if he or she does not apply it and executes a will by hand, or orally, it is the testator, and not his statutory heirs, who should bear the risk of imprecise expression of such a will ${ }^{14}$. All this leads to the conclusion that the interpretation of the will within the meaning of Art. 948 of the Civil Code is a process of interpreting the testator's will that allows it to be clearly defined.

14 As Zbigniew Radwański points out in, "Wykładnia testamentów," Kwartalnik Prawa Prywatnego, no. 1 (1993): 24, the testator should be required to demonstrate a minimum of responsibility when formulating his or her last will, shall it become properly executed after their death. 
Therefore, it seems that although the regional court's question was based on a certain simplification (the obligation to clearly define the grounds for determining the heir was not derived from the limits of the interpretation of the will), the Supreme Court should specifically answer the second of the legal questions asked by the questioning court in the above-mentioned manner.

\section{REFERENCES}

Gwiazdomorski, Jan. Prawo spadkowe w zarysie. Warszawa: Państwowe Wydawnictwo Naukowe, 1985.

Niedośpiał, Michał. Testament. Zagadnienia ogólne testamentu $w$ polskim prawie cywilnym. Kraków-Poznań: Polski Dom Wydawniczy „Ławica”, 1993.

Osajda, Konrad. In Kodeks cywilny. Komentarz. Tom III. Spadki (art. 922-1088), edited by Konrad Osajda, 318-329. Warszawa: C.H. Beck, 2013.

Radwański, Zbigniew. "Wykładnia testamentów." Kwartalnik Prawa Prywatnego, no. 1 (1993): 5-30.

Rzewuski, Maciej. "Wykładnia słusznościowa testamentu.” Biatostockie Studia Prawnicze, no 17 (2014): 227-236.

Rzewuski, Maciej. "Wykładnia testamentu a okoliczności zewnętrzne towarzyszące testowaniu." Przeglad Sądowy, no 1 (2015): 106-119.

Wierciński, Jacek. "Uwagi o zamiarze testowania." Przeglad Sądowy, no. 7-8 (2012): 132-143.

Wójcik, Sylwester. "Rozrządzenia testamentowe." In System Prawa Cywilnego, Tom IV, Prawo spadkowe, edited by Józef Stanisław Piątowski, 220-270. Wrocław-Warszawa-Kraków-Gdańsk: Wydawnictwo Polskiej Akademii Nauk, 1986. 